This is the author's peer-reviewed, post-print manuscript as accepted for publication. The publisherformatted, penultimate version may be available through the journal web site or your institution's library.

\title{
The Reference Librarian as Non-Expert: A Postmodern Approach to Expertise
}

Mark Stover

\section{Manuscript Citation:}

The following APA style citation may be used to reference this manuscript:

Stover, M. (2004). The reference librarian as non-expert: a postmodern approach to expertise. Retrieved from http://scholarworks.csun.edu

\section{Version of Record Information:}

Citation: Stover, M. (2004). The reference librarian as non-expert: a postmodern approach to expertise. The Reference Librarian, 42(87/88), 273-300.

Copyright: Copyright $\odot$ The Haworth Press, Inc.

(DOI): 10.1300/J120v42n87_10

URL: http://www.tandfonline.com/doi/abs/10.1300/J120v42n87_10 


\title{
The Reference Librarian as Non-Expert: A Postmodern Approach to Expertise
}

\section{By Mark Stover}

\begin{abstract}
This article explores the postmodern psychotherapeutic view of the therapist as a non-expert. The author seeks to draw an analogy between the professional expertise and knowledge of the reference librarian and the expertise of the psychotherapist, with special reference to the postmodern idea of the posture of non-expertise. Reference librarians will provide a higher degree of user satisfaction to patrons when the reference interview is approached as a collaborative and dialogic process that is grounded in the attitude of non-expertise. The stance of the reference librarian as non-expert will move the profession of librarianship away from the technocrat/expert model and back towards its earlier mission of service and human-centered values.
\end{abstract}

Keywords: Postmodernism; Reference Services; Expertise

\section{Introduction}

The modern world is obsessed with the idea of knowledge and expertise. ${ }^{1}$

Specialized knowledge is highly valued in the "knowledge society" that is driven by an “information economy." 2 The field of librarianship is no exception. Librarians have for 
many years been concerned about the professional status of their work. ${ }^{3}$ As other professions have discovered, the best and surest way to achieve true professional status in society is to develop expertise in a particular area. ${ }^{4}$ Librarians have followed this course and have postured themselves, rightly or wrongly, as “information professionals,” adept at the selection, organization, dissemination, and preservation of the world's databanks and knowledge stores. ${ }^{5}$ As Rowland writes, librarians are "professional information managers whose role is to guide students and researchers through the confusing maze of products and services that have proliferated in a very few years.” 6

At approximately the same time that the post-industrial society began to evolve into an information complex, a philosophical movement started to spread throughout Europe and the United States and began to change the ways that the world was viewed. Postmodernism, a term that is perhaps overused and often misunderstood, has become a potent idea in a variety of academic and professional disciplines today. The postmodern perspective has made important inroads in the field of psychotherapy, where a large number of books, journal articles, conferences, and theoretical modalities exist that claim the rubric of "postmodern therapy." The therapeutic incorporation of postmodern philosophy has a number of different facets that make it unique. The one aspect that is important to this article is the idea of expertise.

This article examines the nature of librarian expertise and the postmodern phenomenon. It seeks to draw an analogy between the professional expertise and knowledge of the librarian (primarily the reference librarian) and the expertise of the psychotherapist, with special reference to the postmodern idea of the posture of nonexpertise. The stance of the librarian as non-expert moves the profession of librarianship 
away from the technocrat/expert model and back towards its earlier mission of service and human-centered values.

\section{Postmodernism}

The twentieth century witnessed an unusual philosophical movement that crossed disciplines, shattered assumptions, infiltrated popular culture, and radically altered the landscape of contemporary academic discourse. This movement is commonly known as postmodernism. While specific applications may vary from discipline to discipline, the term has come to mean a relativistic perspective on the world. Postmodernism critiques (or deconstructs) accepted standards of society and adopts instead a more flexible, nonjudgmental, pragmatic way of looking at life.

Modernism finds its roots in the Western philosophical tradition that highly valued certainty, truth, closure, and hierarchy. The individual human being was at the center of the universe. It was a "monovocal discourse" that viewed "the knower as autonomous and separate from that which he or she observes, describes, and explains, whether of a physical nature like a storm or of a human nature like crowd behavior. The individual knower is the source of and validator of all knowledge. The individual is privileged."7

Postmodernism emphasizes human relationships and communication as primary.

Stories, meaning, and categories are all by-products of social interaction or relationships. ${ }^{8}$ Creation of meaning is a key component of postmodernism. ${ }^{9}$ According to the postmodernist worldview, an external, tangible reality cannot be known. Postmodernists dispute the Cartesian epistemology that views knowledge as representative and reflective of the "real world."10 


\section{Psychology and Postmodernism}

Along with many other disciplines, the field of psychology (especially the subdisciplines of social psychology and clinical psychology, and the general practice of

psychotherapy) experienced a postmodern awakening. ${ }^{11}$ Psychotherapy originated with Freud and his followers as an individualistic and psychodynamic discipline. Later, family therapists came to see the individualistic therapy model as incomplete and superficial. Systemic psychotherapists, building on systems theory, saw therapy as encompassing not only the family but also broader social networks and even entire communities as important pieces in the greater family system. ${ }^{12}$

Postmodern therapeutic models moved away from finding pathology in the family (the medical model derived from Freud) to finding solutions and ways of connecting within a system. Under the original psychotherapeutic models espoused by Freud and his followers, individuals seeking clinical help from a psychoanalyst were assumed to be sick. Systemic family therapy improved this model somewhat, but the entire family was still viewed as dysfunctional. Postmodern therapies have shifted away from this pathological model and instead focus on positive attributes that can help change a family or an individual.

Postmodern psychotherapy recognizes that nothing is neutral in life. The therapist is not neutral, the client is not neutral, the family is not neutral, and society is not neutral. Instead of acceding to the myth of neutrality, the postmodern therapist works with the biases and inner stories of the client to create a new, healthier reality.

Instead of replacing the "faulty" narratives of the client with the "superior" 
narratives of the therapist, postmodern therapists seek to assist the client in constructing new and healthier life stories through relational discourse. According to one psychologist, "the therapist becomes a collaborator, a co-constructor of meaning." "13 The therapist is no longer the "expert” who can interpret reality for the client. Instead, the therapist and the client work together to build on each other's expertise.

\section{Expertise and Postmodernism}

The concept of "expert" is a decidedly modern idea. It has its roots in ancient classical thought, and it matured during the middle ages, but the view that one could lay claim to mastery over a particular domain fully blossomed first during the Renaissance and then later in the age of rationalism. The modern view of expertise reached its zenith when philosophers and scientists of the early twentieth century embraced the idea of positivism.

The "modern" view of knowledge and expertise is that these entities are objective and separate from the people who make use of them. Knowledge is independent of the knower. It privileges, legitimizes, and empowers those with knowledge, especially special or esoteric knowledge. Knowledge cumulates throughout history, resulting in "univocal metadiscourses” which are much more important to the modernist than personal experiences and individual narratives. ${ }^{14}$

Postmodernists generally hold a qualified view of expertise in light of political and other biases that might cloud and distort the expert's vision. ${ }^{15}$ Anderson writes, somewhat pejoratively, that "experts hold a dualistic, hierarchical position in which their knowledge supersedes clients' marginal or everyday nonprofessional knowledge." 16 
To the postmodernist, expertise is inextricably tied to knowledge and power.

Freedman and Combs argue that the discourse of a culture determines what knowledge is true and right in that culture, so "those who control the discourse control knowledge. At the same time, the dominant knowledge of a given milieu determines who will be able to occupy its powerful positions.” 17

\section{Expertise and Power}

Postmodernists believe that expertise and knowledge are not value-neutral. On the contrary, expertise develops out of "social relations within which power is mediated and reproduced.”18 Thus, power and authority are at the center of expertise. The professional expert typically sets the agenda for any work that is to be done on behalf of the client; this in itself assumes a powerful, “one up” stance for the expert and a dependent, “one down” stance for the client. ${ }^{19}$

In the modern view of expertise, the client is dependent on the expert, who stands in a hierarchically superior position. ${ }^{20}$ The expert is essentially “one up” on the client. This dynamic has been seen by some as "a form of practice that maximizes professional control to maximize professional self-interest."21 In most professional work, especially those where the clients are unsophisticated and relatively powerless, the professional acts as a monopolistic gatekeeper to both resources and knowledge to create an impenetrable façade that few if any clients can overcome. ${ }^{22}$

Another aspect of expertise that creates a one up structure is the language that experts use. Specialized knowledge is often unintelligible to the layman, especially when it is conveyed using technical jargon. ${ }^{23}$ 
Non-experts generally are deferential to experts. They do not challenge the judgment of the expert or ask for explanations beyond what the expert is willing to give. The expert is thus autonomous. ${ }^{24}$ This deference sometimes causes resentment and fear on the part of the non-expert. ${ }^{25}$ However, the expert's authoritative stance may also provide a semblance of comfort for the client, and thus makes it easy for the client to give up the right to make judgments and decisions. ${ }^{26}$

The postmodern relationship between an expert and a client is not based on hierarchical differences between the two individuals. Rather, it is based on mutual respect and a desire to learn through conversation. Schon ${ }^{27}$ pioneered the idea of the “reflective practitioner” whose relationship with the client was more like a conversation between peers than a hierarchical monologue. He writes:

"Just as reflective practice takes the form of a reflective conversation with the situation, so the reflective practitioner's relation with his client takes the form of a literally reflective conversation. Here the professional recognizes that his technical expertise is embedded in a context of meanings. He attributes to his clients, as well as to himself, a capacity to mean, know, and plan. He recognizes that his actions may have different meanings for his client than he intends them to have, and he gives himself the task of discovering what these are. He recognizes an obligation to make his own understandings accessible to his client, which means that he needs often to reflect anew on what he knows.”28 
A postmodern expert's knowledge is constructed again and again, and may change depending on the client's needs and experiences. While there is no question that experts should be technically competent and credentialed when necessary, the expert's authority is based on her ability to demonstrate special knowledge through client interaction. ${ }^{29}$ The postmodern concept of expert should be thought of as a type of interaction rather than embedded in a person. Experts, in the postmodern framework, exist only because there is someone who has a particular kind of knowledge for which someone else has a need. $^{30}$

\section{Expertise in Psychotherapy}

From a "modern" point of view, the psychotherapist is one up. He is a "metaknower" of pathology and an authority on the way that people should live their lives. Anderson and Levin write that "as therapists draw from professionally and culturally legitimized psychotherapy knowledge or narratives, their voices are privileged over their clients.”31

Medical practice (from which psychotherapy is derived) is rooted in the modern model of expertise, which fosters "hierarchical and dualistic structures and expertnonexpert relationships.”32 The physician holds privileged information, and the patient must almost always defer to the physician's greater knowledge, skill, and experience, which is “often private and unavailable to a patient."33

Like physicians, psychotherapists are often perceived as having a level of 
knowledge and expertise that is miles above that of their patients. ${ }^{34}$ But postmodern therapists recognize that there are two kinds of knowledge: esoteric (professional) knowledge, and shared knowledge. The question of professional knowledge versus shared knowledge thus becomes ethical in nature. The psychotherapist must decide which ethical stance he will take as a practitioner. ${ }^{35}$

Postmodernism suggests that those in power are the ones who control the flow of information and who ultimately tell the stories. Thus, a therapist in the traditional therapeutic modality will control the narrative of her client, and therefore reflect more of her sense of reality than that of the client. ${ }^{36}$ But a postmodern therapist will allow the client to control his own narrative and in so doing take responsibility for his own future. ${ }^{37}$

Postmodern psychotherapeutic modalities seek to empower the client through a variety of means. Primary in this model is shared knowledge between the therapist and the client. The therapist "reveals" any "esoteric knowledge" that she may have, and the client in turn discloses any relevant information that he may have (which indeed may be critical to the successful outcome of the therapy).

Change in therapy comes from the partnership between client and therapist. The dialogic conversation that takes place in therapy forms the basis for a new identity for the client. The expertise of the therapist is not so much her knowledge of abstruse theories of the mind or complex diagnostic criteria but her ability to participate in the process of collaborative therapy. ${ }^{38}$

Postmodern therapists believe in the idea of shared expertise. The client drives the conversation and tells his story. The therapist thinks of herself as a learner, not an 
omniscient, all-wise god. Therapy is fluid and mutual, and ultimately is a "shared inquiry” that "has a give-and-take, back and forth, crisscrossing nature.”39 It is collaboration in the best sense of the word. Collaborative relationships promote respectful and productive interactions. The stance that the postmodern therapist takes is one of openness and curiosity. This therapist sees therapy as "shared responsibility and accountability."40

In postmodern psychotherapy, the therapist takes a "not knowing” stance rather than a "knowledgeable" position. The therapist will thus ask open-ended questions rather than questions informed by her particular theoretical position and that require specific answers. In other words, the therapist allows the client's story to push the agenda rather than her own biases. "Not knowing” does not propose a naive or ignorant perspective, but rather that the therapist lay aside her assumptions and theoretical leanings and simply hear the client's story on his own terms. A more “knowledgeable” approach might validate the therapist's own pet theories but would de-legitimize the client's personal narrative. The therapist's knowledge, especially in relation to the client, is tentative and is open to change. ${ }^{41}$

Postmodern therapies propose that clients take personal responsibility for their lives. The client has the authority, competence, and expertise to manage his own situation inventively and creatively. Anderson calls this aspect of postmodern therapy "self-agency."42

Critics of the postmodern therapies assert that a "truly expert-free therapy" is not ideal and indeed not even possible. ${ }^{43}$ But postmodern therapists respond that this 
argument is a straw man. Psychotherapy in the postmodern view does not seek to be expert-free, but rather seeks to use one's expertise in a multidimensional way without resorting to hierarchical and authoritative models.

\section{Expertise in Librarianship}

Expertise in modern librarianship has been depicted in a number of ways. Some authors describe expertise in terms of effectiveness, ${ }^{44}$ and often attempt to measure the level of performance. Others write about the role of the librarian in ascribing authority to information through the selection and acquisition process. ${ }^{45}$ Crowley $^{46}$ speaks of the "tacit knowledge" of the librarian, which he defines as "the often-undocumented wisdom possessed by expert practitioners. ${ }^{\text {47 }}$ Some speak of the librarian’s special knowledge. ${ }^{48}$ Still others write about the authentication role of librarians. ${ }^{49}$ "[S]ociety requires credible gatekeepers of information, and has entrusted some of that function to universities and its resident experts,"50 who include librarians.

Librarians often posture themselves as experts. ${ }^{51}$ The library profession speaks of super searchers, expert systems, ${ }^{52}$ knowledge navigators, master librarians, and subject expertise. ${ }^{53}$ Typical of the discourse of librarian expertise is the following assertion: “Academic librarians have retooled themselves continuously. Upgrading their knowledge, skills, and abilities, librarians now are experts in the use of new technologies." 54

It is clear that librarians, like other occupational groups, must make a commitment to acquiring technical skills and mastering foundational principles. ${ }^{55}$ Training and experience (and ultimately intuition) generate expertise. Talent, capabilities, interests, 
intrinsic motivations, and "time to master the domain knowledge" all create expertise. ${ }^{56}$

There are political ramifications to librarian expertise. According to some, a great deal of political capital could be gained if librarians were viewed as skilled experts. ${ }^{57}$ The converse is true as well. Librarians may believe that a loss of status and prestige will result if the general public were to view them as "non-experts."

\section{Reference Expertise}

Reference librarians typically give three kinds of assistance to users: bibliographical assistance (finding a book or document in the library or outside of the library); question answering (finding the answer to a specific, fact-based question); and selection assistance (recommending a book for a specific purpose). ${ }^{58}$

Librarians do not take part in (and indeed are proscribed from engaging in) inference, synthesis, interpretation, or other kinds of evaluative activities. Librarians are prohibited by professional consensus from answering questions out of their own personal knowledge without verifying the answer from a recognized source. Similarly, reference librarians will usually not take personal responsibility for the accurate nature of the information they provide, since it comes from other sources and not from their own knowledge. $^{59}$

The alleged 55\% success rate in reference transactions, also known as "half right reference," has been discussed in the literature both by those who cite it as a fact of library life, ${ }^{60}$ along with those who believe it does not accurately reflect the state of affairs at the reference desk. ${ }^{61}$ Wilson argues that librarians are not necessarily supposed 
to give the correct answer every time, but only what the standard reference sources say is the correct answer. ${ }^{62}$ Whitlatch demonstrates that just as important as the reference librarian's knowledge of the "facts" is feedback from the patron and the service orientation of the librarian. ${ }^{63}$

Richardson ${ }^{64}$ estimates that only about five percent of reference librarians are truly experts. Most may be proficient and competent, but expertise is more than competency. Thomas, Hinckley, and Eisenbach agree, stating that every good reference librarian has “a successful mixture of competence and imagination., 65

Whitlatch ${ }^{66}$ describes various ways of measuring the quality of the reference interview, including librarian behavior, librarian effort, librarian knowledge, and librarian communication skills. Harris and Michell ${ }^{67}$ demonstrate that patron perception of librarian competence and expertise is often tied to non-verbal communication during the reference interview rather than actual outcomes. Quinn ${ }^{68}$ shows that attitude and interpersonal skills are often just as important for reference librarians as information retrieval skills.

\section{Knowledge Base of Librarianship}

Expertise is often related to a professional knowledge base. The knowledge base of an occupation or profession is simply the cumulative social or technical knowledge necessary to perform in that particular occupation. It is the duty of the specialist to help maintain the knowledge base of his or her profession. "Initial mastery" of the knowledge base is a "minimal condition for entry into the occupational group." emphasis on knowledge must never lead to neglect of the applied aspects of any 
profession. Knowledge, especially in the professions, must be applied to be useful. In fact, for professionals, pure knowledge without application is an oxymoron. ${ }^{70}$

Professional knowledge often appears esoteric to outsiders simply because of the specialization involved and the "inevitable social distance created by a highly differentiated social structure.”71 However, a substantial knowledge base allows a profession to maintain a certain degree of autonomy, since outsiders cannot easily master its contents and practical application. ${ }^{72}$

Does librarianship have a special knowledge base? Debate has raged concerning this question. Some believe that the librarian's formal educational process, combined with the technical skills that are often required and a commitment to free access to information, clearly make the argument for a theoretical knowledge base. ${ }^{73}$ Others disagree, asserting that this ephemeral knowledge base is simply "a contrived mystique to keep the laity uninformed and powerless.",74

If a knowledge base in librarianship does exist, does this imply that the librarian has specialized or esoteric knowledge? If so, is this knowledge a form of expertise in mediating access to information? Is it familiarity with subject content? Is it familiarity with the arcane rules of cataloging and classification? Is it an expert knowledge of online database searching?

There are a number of writers who deny the special nature of librarians' knowledge base. $^{75}$ Gwinup asserts that librarians are engaged in routine tasks most of the time. ${ }^{76}$ Asheim states that librarianship has been inadequate in creating "an intellectually respectable body of knowledge and theory."77 
Despite the skeptics' denials, librarianship does appear to have a corpus of knowledge "accumulated over the past century." ${ }^{78}$ However, it is undoubtedly safe to say that if indeed there is a knowledge base of librarianship, it is mostly derivative. That is, it borrows many of its ideas from other disciplines, such as social psychology and management science. Its intellectual core is made up of two distinct (but intertwined) areas: classification and the theory of intellectual freedom. ${ }^{79}$

Among those who concede that librarianship does have a base of knowledge are some who assert that much of this knowledge base is fairly mundane. According to Richardson, ${ }^{80}$ about 20 percent of reference knowledge is made up of "declarative facts,” and 80 percent is made up of procedural rules.

Some believe that the knowledge base of librarianship goes beyond a set of theoretical facts to include a unique combination of knowledge, skills, and attitudes. Marchionini asserts that successful information seekers must have a wide variety of attributes, including general cognitive facility, domain expertise, system expertise, information-seeking expertise, and the ability to find patterns and develop strategies. ${ }^{81}$

Clearly, librarians must have a broad spectrum of knowledge and talents. They must be literate, versatile, and highly skilled in evaluating, classifying, and retrieving information. $^{82}$ Their ancillary knowledge must include organizational, environmental, cultural, and physical structures of libraries. But the librarian must also have more fundamental knowledge, which relates to the function or role of the library. Librarians must know the content of the information, and they must know what their users want (and how their users seek information), and finally librarians must know how to put 
information into the hands of their users. ${ }^{83}$ The California Library Association, in a landmark document entitled “The Future of Librarianship”, echoes these sentiments with the following statement: "The core professional expertise of librarianship is at the confluence of three areas -- information, information technology, and users.”84

Shera writes that the knowledge base of librarianship primarily concerns the interaction between information seekers and information. ${ }^{85}$ He distinguishes between academic specialists, such as physicists, chemists, or historians, and professional workers, such as librarians. Academicians must be intimately acquainted with three important areas: the theoretical framework of the field, the appropriate methods of research, and the major contributions to verified knowledge. But the professional is different. He or she must blend theory and practice, art and science. "If there is an excess of know-how the profession degenerates into a mere craft, while too much theory leads to the sterility of empty formalism.”86 All professions are necessarily interdisciplinary, but librarianship is perhaps the most so. Shera asserts that librarianship of all professions "is probably the most derivative and synthetic, is most dependent upon the more formal disciplines for the derivation of its own theoretical structure and its corpus of practice.”87

\section{Librarians, Expertise, and Positivism}

There is a well-established belief within librarianship that libraries and library staff can be evaluated and measured quantitatively in terms of effectiveness and excellence in customer service and other aspects of library work. This idea, which Budd demonstrates is part of a long tradition of library research and practice, is directly related to the 
acceptance of positivism among librarians and library researchers. ${ }^{88}$ The expertise of the librarian as seen from the positivistic perspective is another example of the influence of scientism on library praxis.

Another question that reflects the debate between positivism and postmodernism is whether knowledge is created or discovered. The "modern" view of traditional librarianship assumes that library users (researchers) are passive in their research in that they "discover" facts that "exist outside language and thinking," facts that "can, in principle, be discovered by anyone." 89 Critics of this perspective claim that research is actually an active process whereby knowledge is created through discourse or linguistics. $^{90}$

Some believe that an expert stance, born out of positivism, is unhelpful to library clients. The positivistic and objectivist stance of traditional librarianship may create a disempowering climate for library users. ${ }^{91}$ This traditional posture asserts that for every reference question there is a factual answer or a "best" source, for every information seeker there is a perfect query, and that for every book there is one ideal subject heading. One author states that "library scholarship is becoming aware of the underlying positivist epistemological foundation for library science and how negative tensions and stereotypes arise from the polarizations that such a stance takes as axiomatic." ${ }^{92}$ Another writes that we are "in danger of beginning to think of libraries as businesses that provide primarily electronic information and facts rather than materials to support humanistic knowledge and insight." 93 
Jargon and Expertise in Librarianship

The jargon of librarianship may contribute to an overemphasis on expertise among librarians. Several authors have commented on the technical language, acronyms, and buzz words that continually inundate the language of the library profession. ${ }^{94}$

Naismith and Stein found that public encounters between librarians and patrons often include jargon. ${ }^{95}$ In the reference interview, jargon may be an impediment to a successful transaction. The authors assert that "patrons misunderstand library terms approximately half of the time." ${ }^{\text {966 }}$ Another author contends that library jargon, often borrowed from the computer and business world, is impersonal, ugly, and obfuscatory. ${ }^{97}$ While sometimes necessary for technical precision purposes, jargon does tend to reinforce the superior stance of the expert.

\section{Librarians, Knowledge, and Emotional Expertise}

Budd $^{98}$ has created a taxonomy of knowledge for librarians: practical knowledge, theoretical knowledge, and ethical knowledge. The three must be intertwined; they cannot be separated without a failure of some sort. A reference librarian with this kind of knowledge recognizes that a "just the facts" approach is lacking in many ways. She takes a holistic view of library encounters and puts a human face on the reference interview. This attitude and behavior might be described as "emotional expertise."

The expertise of the reference librarian must go beyond familiarity with knowledge in general and a particular subject domain. It must include verbal skills, social psychological abilities, rudimentary quantitative skills, and a deep understanding of 
modern society. ${ }^{99}$ Reference librarians often use tacit knowledge and undocumented expertise, in that they tend to be intuitive and reflective practitioners. ${ }^{100}$ The skills required of reference librarians are multi-faceted, and include various domains including the “technical, cognitive, and behavioral."101

Communication of information is at the heart of the librarian's work. ${ }^{102}$ A person with less knowledge but greater communication skills or intuition will provide better reference service, since "having a large store of knowledge does not guarantee the ability to formulate suitable answers." ${ }^{103}$ A good reference librarian must be able to "adopt the standpoint of another and see what would suit his purpose. ${ }^{104}$

Librarians must be good listeners and interpreters. They must use their intuition and be sensitive to the cues they receive from their clients. They must use good judgment in the reference interview. ${ }^{105}$ Abilities in human relations or communication skills are necessary and critical to successful professional delivery of service, going beyond any rote knowledge or theoretical expertise that might be a more superficial requirement for the professional. This is clearly the case in reference librarianship. ${ }^{106}$

Richardson ${ }^{107}$ has compiled a number of "mental traits” that define the successful reference librarian. These include several attributes that are not traditionally associated with the concept of expert, such as dependability, courteousness, tact, interest in people, pleasantness, cooperativeness, poise, patience, neatness, helpfulness, empathy, sensitivity, and humor. Perhaps expertise in reference librarianship is related more to “emotional intelligence” than to traditional notions of intelligence. ${ }^{108}$

\section{The Reference Librarian as Collaborative Psychotherapist}


A comparison between therapists and librarians is not unheard of in the literature. ${ }^{109}$ Both professions (psychotherapy and librarianship) are "helping" professions, both involve "conversations" between the "expert" and the client, and both professions seek to solve specific problems through "diagnosis" and "treatment." As McGowan and Dow note, “clinicians diagnose and manage medical problems” whereas "librarians diagnose and manage information problems.”"110

But these comparisons are somewhat superficial and continue to rely on the traditional view of the therapist (and the librarian) as expert. As has been demonstrated earlier in this paper, the idea of "predetermined professional knowledge and its influence on client-professional relationships” is being challenged in the field of psychotherapy as well as in other professions. ${ }^{111}$ Collaboration between professional and client has become more highly valued. Self-reflection, feedback and relational skills have become more important than a static view of expertise and specialized knowledge. Ultimately this collaboration enhances the professional's performance and the client's satisfaction. ${ }^{112}$

I would propose that there is an analogy between the new postmodern theories of psychotherapy (where the therapist takes a decidedly "non-expert” posture) and the ways that librarians work with patrons seeking information. Nardi and O'Day call what librarians do "information therapy" and write that "interacting with a reference librarian can be very much like going to a good psychotherapist who, through skillful questioning, gets you to talk about what's really bothering you.” ${ }^{113}$ Reference work is a conversation, not a monologue, in which the librarian (like the postmodern psychotherapist) and the client together construct the information scenario. ${ }^{114}$ Neither the librarian nor the client could create this unique transaction by himself or herself. Like the postmodern therapist, 
the librarian as non-expert does not impose the "answer" on the client, but rather works with the client to seek solutions in a collaborative manner. The reference interview, like postmodern therapy, "is a creative, interactive process, to which each person brings special expertise and knowledge." ${ }^{115}$ Thus, one can distinguish in this process between expert knowledge (which both librarian and client have) and expert posture (which involves attitudes, behaviors, and actions).

There is almost always a difference between the literal request of the client and what the client actually needs. The reference interview, like therapy, is a fluid conversation that should draw out these needs. The reference negotiation needs to be "subtle, nuanced, tactful, and delicate."116 Different clients with different situations demand different tactics and different tools. "The ineluctable human touch [should be] present in these encounters." ${ }^{117}$ The human-centered aspects of reference librarianship must be foremost, especially as the world of information resources becomes more and more computer-oriented. ${ }^{118}$ The non-expert stance of the librarian encourages sensitivity and humanity in the reference interview.

Just as in psychotherapy, there is a dialogic aspect to the reference interview. This interaction can either become a true conversation with many possibilities or a monologue limited to the librarian's point of view. If it is a dialogue, it must be an intentional act that consciously focuses on allowing other points of view into the conversation. ${ }^{119}$

Librarians, like therapists, should pursue the empowerment of their patrons rather than the maintenance of their own power. ${ }^{120}$ Most experts who render services do not change their clients; the service is rendered and the client moves on, often untouched by 
the experience and still in an unequal relationship with the expert. But the librarian whose patron is still dependent even after instruction and guidance has failed in his or her professional capacity. $^{121}$

Just as the postmodern therapist strives to help create a self-sufficient client, so the reference librarian should focus on the innate or potential competence of the library user. $^{122}$ Bunge writes that "the reference librarian needs to believe the client is capable of recognizing his or her own need and of knowing when useful information has been found to serve it. One of the key concepts of client-centered helping ... is that the professional approaches the client as competent and able, rather than as incompetent and needing manipulation.”123

There are many examples of how the special knowledge or expertise of the reference librarian can actually impede the success of the reference process. The librarian can answer the very first question (or respond to the very first comment) of the patron without negotiating the question. For example, the question "Where are your journals?” can be answered in a straightforward manner, but it will likely be unhelpful to the patron who is most probably looking for (whether he knows it or not at the time) subject access to the journal literature, not the physical location of journals in the library. This premature response, while technically “correct,” fails to ultimately assist the patron in finding the information necessary for a successful information seeking outcome. The expertise and authority of the librarian (knowledge of the library) actually reinforces the “ignorance” of the patron and is likely to lead to patron frustration in the information search process. 
Another example demonstrates the complexity of the reference interview and the collaborative nature of the reference process. The reference librarian may respond to a question about medieval history by pointing to a variety of sources, including print, online, and Web-based tools. This answer showcases the librarian's knowledge of the subject. But again, the lack of a substantive reference interview reveals the weakness of such an "authoritative” approach. Several open-ended questions need to be asked to assist the patron is locating the appropriate information. How much information is needed? (The initial response, a showcase of the librarian's knowledge, may prove to be overkill and thus unnecessarily create information overload). For what purpose do you need this information? (Although controversial due to a desire to maintain patron privacy, this question often needs to be asked to ascertain appropriate tools and sources). Where have you looked so far? (Failure to ask this question may result in a redundant monologue on the part of the librarian).

While collaborative, open-ended, and interactive reference interview techniques are important, the attitudinal posture of the librarian is even more crucial to a successful outcome of the process. The stance of the librarian as expert may convey an arrogant attitude to the patron and may result in intimidation, subservience, or antipathy. The nonexpert posture conveys acceptance and mutual respect, and is more likely to result in a successful outcome through collaborative efforts and shared expertise.

\section{User Satisfaction and Reference Librarianship}

Most user satisfaction studies in the library literature note the necessity of 
interpersonal skills for high levels of customer satisfaction. Nitecki writes that the human-centered qualities of reliability, responsiveness, assurance, and empathy are all important criteria for user satisfaction. ${ }^{124}$ Jardine found that users expressed satisfaction based on a number of factors, including "interest, confidence, friendliness, and enthusiasm." 125 Other attributes found necessary for user satisfaction include a friendly and approachable demeanor, ${ }^{126}$ active listening abilities, ${ }^{127}$ smiling and establishing eye contact, ${ }^{128}$ and general interpersonal skills. ${ }^{129}$

User satisfaction studies reveal that many interpersonal factors (apart from the factual answering of the reference question) are involved in the success of the reference interview. Since a postmodern non-expert posture encourages interpersonal, humancentered, collaborative skills and behaviors, it is reasonable to infer that if reference librarians wish to provide a higher degree of user satisfaction, they should discard the superordinate attitudes of the modern expert in favor of the postmodern posture of a collaborative non-expert.

\section{The Postmodern Librarian as Non-Expert}

In Umberto Eco's modern classic novel The Name of the Rose, one of the characters asserts that "the library is testament to truth and to error." ${ }^{130}$ This statement is a medieval postulation that was widely held even into modern times, but postmodernism allows us more perspective than our colleagues in the middle ages. Librarianship must be based on relationships and communication, or it will ultimately fail. No one, not even the librarian, is the keeper of the truth.

But the question remains: Are reference librarians experts? The answer is 
complex. Librarians do match many of the accepted prerequisites for expert status, such as professional (or vocational) utilization of knowledge, problem solving through diagnosis and prescription, and greater speed and accuracy in performing tasks than nonexperts. In addition, despite complaints of low salaries, most librarians have been able to turn their professional knowledge into economic viability, another mark of membership in the society of experts. ${ }^{131}$

Librarians are not experts in the same way that scientists are experts or physicians are experts. Still, reference librarians do function with a certain level of expertise, which is grounded in theory, rules, subject knowledge, and intuition. ${ }^{132}$ In addition, reference librarians must demonstrate a high degree of emotional expertise, including empathy and other social competencies, if they are to be successful in the reference transaction. ${ }^{133}$

But there is a difference between practical expertise and the posture of “expertness.”134 Experts often alienate their clients with their privileged stance and superior attitude, which I call the "expert alienation syndrome.” Clearly, reference librarians will wish to avoid this kind of client relationship.

In the final analysis, reference librarians should be more like postmodern therapists than modern experts, at least in terms of their attitudes and goals. They assist patrons in finding information, but they should not dictate the terms of the end to a successful search. Meeting the information needs of the client is foremost, not the nebulous "search for ultimate truth.” Answering reference questions accurately is important, but in many ways attitudes, actions, and non-verbal communication are just as important as factual authenticity for quality reference service. ${ }^{135}$ The postmodern posture of non-expert allows 
reference librarians to focus on a full-orbed approach encompassing a collaborative style, a friendly demeanor, and an approachable presence, as opposed to a "just the facts" expert stance that may appear condescending and cold.

Most librarians probably do not think of themselves as arrogant in the way that they view information seeking. Yet, librarians often marginalize the idea of information seeking through personal contacts, despite studies that have shown that this method is how many researchers choose to search for information. ${ }^{136}$ In the same way, browsing the stacks is a tried and true method of information seeking for many library patrons. Librarians often decry this methodology, but again, this attitude may come from a professional arrogance rooted in the librarian's own preferences and training

Michael Gorman has written about the values of librarianship, especially as these values relate to reference librarians. ${ }^{137}$ Some of these values include the value of service to patrons, the value of intellectual freedom, the value of literacy and learning, and the value of equity of access to information. When viewed through the lens of the postmodern "non-expert” librarian model, these values take on an added dynamic. For example, the value of service to patrons is strengthened when librarians stop viewing themselves as superordinate in the librarian-client relationship. Intellectual freedom is reinforced when librarians (as “non-experts”) are less secretive about their professional knowledge. Literacy and learning are supported when the reference interview is dialogic instead of monovocal. Equity of access to information is encouraged when professional librarians, who may indeed have expertise in knowledge and practice, begin to see themselves as on a par with patrons instead of in a privileged and superior position. 
The postmodern reference librarian, like the postmodern therapist, is interdependent and collaborative, not autonomous. ${ }^{138}$ She puts herself on an equal plain with her clients, as opposed to the "one up” superior stance that is sometimes postured by “experts.” She is willing to share her expertise and her knowledge, and does not attempt to keep this knowledge a mystery under the guise of “professional secrets” or proprietary information. She values relationships over brute facts. ${ }^{139}$ The postmodern librarian does not see herself as privileged due to her status and knowledge; indeed, this librarian is able to learn from her clients as much as they are able to learn from her.

The postmodern librarian, like the postmodern therapist, will ask open-ended questions in the reference interview. ${ }^{140}$ She will take a "not knowing” stance and will allow the patron's story to push the agenda. She will share her expertise, not impose it. She will acknowledge that cultural factors often shape the reality of the reference transaction. ${ }^{141}$ She will focus on both content and process. Finally, the postmodern librarian will allow the library patron to take personal responsibility for his or her ultimate success in the information seeking process. ${ }^{142}$

Librarians would do well to follow the "reflective practitioner" model as set forth by Schon. ${ }^{143}$ The reflective practitioner

"agrees to deliver competent performance to the limits of his capacity; to help the client understand the meaning of the professional's advice and the rationale for his actions, while at the same time he tries to learn the meanings his actions have for his client; to make himself readily confrontable by his client; and to reflect on his own tacit understandings 
when he needs to do so."144

With regard to expertise, the postmodern librarian will recognize that the reference desk is not an inherently neutral place. The reference librarian, whether or not she acknowledges it, holds a distinct advantage over most patrons by virtue of her professional status, knowledge, and education. This can lead to a "one down" situation where the patron hesitates (or refuses) to approach the reference desk, or where the patron becomes so intimidated by the librarian that a successful reference interview is impossible. ${ }^{145}$ Most librarians will understand that this power dynamic is a potential barrier to the information seeking goals of the patron.

The reference interview is often viewed through the lens of the traditional medical model. ${ }^{146}$ Thus, the reference librarian performs a diagnosis on the pathology (ignorance) of the patron and then prescribes treatment as well. The postmodern librarian will function more like a constructivist therapist, who learns from (as well as teaches) the client, and who assumes potential growth in the client instead of pathology. ${ }^{147}$

It is certainly true that reference librarians do function in ways that are analogous to medical practitioners. They do perform a semblance of diagnosis, and they often do prescribe a form of treatment. However, reference librarians must avoid the quasiobjective expert stance of the librarian-pathologist if they are to succeed in facilitating the patron's innate abilities to find the information they need.

Postmodern librarians must avoid technocracy (rule of the technical experts). 
Instead, they should strive for collaboration with clients and a holistic understanding of knowledge. Postmodern librarians, deriving values from the non-expert therapeutic model, should be flexible, non-judgmental, pragmatic, conversational, creative, open to new possibilities, relational, and communicative.

Anderson, writing about the postmodern therapist, epitomizes what the reference interview and indeed all library encounters can become:

“Through dialogue, each observation, understanding, and description of the symptom, and each treatment solution, becomes one of many possibilities possibilities that are jointly created within and are products of the local conversation.”148

Postmodern librarians, like postmodern therapists, recognize the power of language in the reference interview. ${ }^{149}$ They stay away from jargon and "professional" terminology (which are often meaningless to the patron) and they carefully structure their questions and statements to avoid falling back into the one up position of the expert. They attempt to demystify the library for the patron through an open and equal dialogue.

The postmodern librarian will recognize that professional resources and professional knowledge are not secret commodities to be protected or monopolized. Instead, this librarian will seek to share these gifts with patrons in a relational, interdependent, and non-hierarchical manner. Coffey and Lawson write that "successful librarians are experts in their field who are able to shed their "expertness” (not expertise, but the attitude of expertise) in order to truly serve, and not alienate, their clientele.”150 
Both knowledge of the library collection and an appreciation for the humanity of reference work are crucial to the success of the reference transaction. As Gorman has written, "lack of sympathy toward the library user can make even the most

knowledgeable reference librarian ineffective.” 151 
1. Pamela J. Hinds, Michael Patterson, and Jeffrey Pfeffer, "Bothered by Abstraction: The Effect of Expertise on Knowledge,” Journal of Applied Psychology 86 (December 2001): 1232-1244.

2. Daniel Bell, The Coming of Post-Industrial Society: a Venture in Social Forecasting, New York: Basic Books, 1973; Frank Fischer, Technocracy and the Politics of Expertise, Newbury Park, CA: Sage, 1990; James Fleck, “Expertise, Knowledge, Power and Tradeability,” in Exploring Expertise: Issues and Perspectives, ed. Wendy Faulkner, James Fleck and Robin Williams, Basingstoke, England: Macmillan, 1998.

3. Andrew Abbott, "Professionalism and the Future of Librarianship,” Library Trends 46 (Winter 1998): 430-443; Pierce Butler, An Introduction to Library Science, Chicago: University of Chicago Press, 1933; Jesse Hauk Shera, The Foundations of Education for Librarianship, New York: Becker and Hayes, 1972; Orvin Lee Shiflett, Origins of American Academic Librarianship, Norwood, NJ: Ablex, 1981.

4. Charles Derber, William A. Schwartz, and Yale Magrass, Power in the Highest Degree: Professionals and the Rise of a New Mandarin Order, New York: Oxford University Press, 1990; K. Anders Ericsson, The Road to Excellence: The Acquisition of Expert Performance in the Arts and Sciences, Sports and Games, Mahway, NJ: Lawrence Erlbaum, 1996.

5. Taodhg Burns and Shahida Rashid, “The New World of Information Professionalism,” Information Outlook 3 (July 1999): 25-29; R.O. Mason, “What Is an Information Professional?” Journal of Education for Library and 
Information Science 31 (Spring 1990): 122-38; Mary Lynn Rice-Lively and J. Drew Racine, "The Role of Academic Librarians in the Era of Information Technology,” Journal of Academic Librarianship 23 (January 1997): 31-41.

6. Lucy M. Rowland, “Libraries and Librarians on the Internet,” Communication Education 43 (April 1994): 144.

7. Harlene Anderson, Conversation, Language, and Possibilities: A Postmodern Approach to Therapy, New York: Basic Books, 1997, 30.

8. Kenneth Gergen, Realities and Relationships: Soundings in Social Construction, Cambridge, MA: Harvard University Press, 1994.

9. Harlene Anderson, “On a Roller Coaster: A Collaborative Language Systems Approach to Therapy,” in The New Language of Change, ed. Steven Friedman, New York: Guilford Press, 1993, 324.

10. Kenneth Bruffee, "Social Construction, Language, and the Authority of Knowledge: A Bibliographical Essay,” College English 48 (1986): 773-90.

11. Jill Freedman and Gene Combs, Narrative Therapy: The Social Construction of Preferred Realities, New York: Norton, 1996; Robert A. Neimeyer and Jonathan D. Raskin, Constructions of Disorder: Meaning-Making Frameworks for Psychotherapy, Washington, DC: American Psychological Association, 2000; Hugh Rosen and Kevin T. Kuehlwein, Constructing Realities : Meaning-Making Perspectives for Psychotherapists, San Francisco: Jossey-Bass Publishers, 1996.

12. Dorothy Stroh Becvar and Raphael J. Becvar, Family Therapy: A Systemic Integration, Boston : Allyn \& Bacon, 2000.

13. Gergen, Realities and Relationships: Soundings in Social Construction, 244. 
14. Harlene Anderson and Susan B. Levin, "Generative Conversations: A Postmodern Approach to Conceptualizing and Working With Human Systems," in The Handbook of Constructive Therapies: Innovative Approaches From Leading Practitioners, ed. Michael F. Hoyt, San Francisco: Jossey-Bass, 1998, 47.

15. Raphael Sassower, Knowledge Without Expertise: On the Status of Scientists, Albany, NY: State University of New York Press, 1993.

16. Anderson, Conversation, Language, and Possibilities: A Postmodern Approach to Therapy, 31.

17. Freedman and Combs, Narrative Therapy: The Social Construction of Preferred Realities, 37-38.

18. Fleck, “Expertise, Knowledge, Power and Tradeability,” 147.

19. The expression "one up," though perhaps colloquial in origin, was first used as a technical term in the literature by Watzlawick, Beavin, and Jackson to describe human communication in family relationships where one member took a superior stance and thereby gained power and authority. See Paul Watzlawick, Janet Helmick Beavin, and Don D. Jackson, Pragmatics of Human Communication: A Study of Interactional Patterns, Pathologies, and Paradoxes, New York: Norton, 1967.

20. Robert Welker, “Expertise and the Teacher As Expert: Rethinking a Questionable Metaphor,” American Educational Research Journal 28 (Spring 1991): 19-35; Wilbert E. Moore, The Professions: Roles and Rules, New York: Russell Sage Foundation, 1970; Mary Lee Bundy and Paul Wasserman, "Professionalism Reconsidered,” College and Research Libraries 29 (January 1968): 5-26. 
21. Lily M. Hoffman, The Politics of Knowledge: Activist Movements in Medicine and Planning, Albany, NY: State University of New York Press, 1989, 6.

22. Eliot Freidson, Professional Powers: a Study of the Institutionalization of Formal Knowledge, Chicago: University of Chicago Press, 1986, 174.

23. Moore, The Professions: Roles and Rules, 226.

24. Donald A. Schon, The Reflective Practitioner: How Professionals Think in Action, New York: Basic Books, 1983, 292.

25. Ericsson, The Road to Excellence: the Acquisition of Expert Performance in the Arts and Sciences, Sports and Games, ix.

26. Lester Asheim, “Librarians As Professionals,” Library Trends 27 (Winter 1979): 22557.

27. Schon, The Reflective Practitioner: How Professionals Think in Action.

28. Ibid., 295.

29. Ibid., 296.

30. Harald A. Mieg, The Social Psychology of Expertise: Case Studies in Research, Professional Domains, and Expert Roles, Mahwah, NJ: Lawrence Erlbaum Associates, 2001, 43.

31. Anderson and Levin, "Generative Conversations: A Postmodern Approach to Conceptualizing and Working With Human Systems,” 47.

32. Anderson, “A Reflection on Client-Professional Collaboration,” Families, Systems and Health (1996) 14(2): 194.

33. Ibid. 
34. Katharine Mair, "The Myth of Therapist Expertise," in Psychotherapy and Its Discontents, ed. Windy Dryden and Colin Feltham, Buckingham, England: Open University Press, 1992.

35. Freedman and Combs, Narrative Therapy: The Social Construction of Preferred Realities, 269-270.

36. Anderson, “A Reflection on Client-Professional Collaboration,” 198.

37. Michael White and David Epston, Narrative Means to Therapeutic Ends, New York: Norton, 1990.

38. Harlene Anderson and Harold Goolishian, "The Client Is the Expert: A Not-Knowing Approach to Therapy," in Therapy As Social Construction, ed. Sheila MacNamee and Kenneth Gergen, Newbury Park, CA: Sage, 1992, 28.

39. Anderson, “A Reflection on Client-Professional Collaboration,” 199.

40. Ibid., 200.

41. Anderson and Goolishian, "The Client Is the Expert: A Not-Knowing Approach to Therapy;” Anderson and Levin, “Generative Conversations: A Postmodern Approach to Conceptualizing and Working With Human Systems.”

42. Anderson, “A Reflection on Client-Professional Collaboration,” 199.

43. Barbara S. Held, Back to Reality: A Critique of Postmodern Theory in Psychotherapy, New York: Norton, 1995, 245.

44. Patrick Ragains, “Evaluation of Academic Librarians’ Instructional Performance: Report of a National Survey,” Research Strategies 15 (1997): 159-75; Charles A. Bunge, "Gathering and Using Patron and Librarian Perceptions of QuestionAnswering Success,” Reference Librarian 66 (1999): 115-40. 
45. G. T. Anderson, "Dimensions, Context, and Freedom: The Library in the Social Creation of Knowledge,” in Sociomedia: Multimedia, Hypermedia, and the Social Construction of Knowledge, ed. Edward Barrett, Cambridge, MA: MIT Press, 1992.

46. Bill Crowley, "Tacit Knowledge and Quality Assurance: Bridging the TheoryPractice Divide," in Knowledge Management for the Information Professional, ed. T. Kanti Srikantaiah and Michael E.D. Koenig, Medford, NJ: Information Today, 2000.

47. Bill Crowley, "Tacit Knowledge, Tacit Ignorance, and the Future of Academic Librarianship,” College \& Research Libraries 62 (November 2001), 566.

48. Elizabeth H. Wood, "Health Sciences Librarianship in the New Millennium,” Medical Reference Services Quarterly 19 (Spring 2000): 1-8.

49. E. M. Noam, "Electronics and the Dim Future of the University," Bulletin of the American Society of Information Science 22 (June/July 1996): 6-9.

50. Ibid., 9.

51. Susan Griswold Blandy, "What to Do Until the Expert Comes: Dealing With Demands for Multicultural, International Information Now,” The Reference Librarian 45-46 (1994): 119-35; Lawrence McCrank, "Reference Expertise: Paradigms, Strategies, and Systems,” The Reference Librarian 40 (1993): 11-42; Paul Jack Weiss, “Getting the Expert into the System: Expert Systems and Cataloging,” The Serials Librarian 25 (1995): 235-41; Danuta A. Nitecki, "Managing Experts: Creating Links Between Librarians, Users, and Systems,” Journal of Library Administration 13 (1990): 59-79; Tim Holthoff, “Expert 
Librarian Applications of Expert Systems to Library Technical Services,” Technical Services Quarterly 7 (1989): 1-16; Frederick Frankena and Joann Koelin Frankena, "The Politics of Expertise and the Role of the Librarian," Behavioral \& Social Sciences Librarian 6 (Fall-Winter1986): 37-47; Olivia Crosby, "Librarians: Information Experts in the Information Age," Occupational Outlook Quarterly 44 (Winter 2000): 2-15.

52. It should be noted here that the phrase "expert system" as applied to libraries and information services is often phrased more delicately as "reference advisory system” or “knowledge-based reference system.” See John V. Richardson, Jr., Knowledge-Based Systems for General Reference Work: Applications, Problems, and Progress, San Diego: Academic Press, 1995.

53. Rory L. Chase, “Knowledge Navigators,” Information Outlook 2 (September 1998): 17-26; Mary Ellen Bates, “The Making of a Super Searcher,” Searcher 7 (November/December 1999): 33-35; Richardson, Knowledge-Based Systems for General Reference Work: Applications, Problems, and Progress; Carol Tenopir, “Are You a Super Searcher?” Library Journal 125 (March 1, 2000): 36-38; Glen E. Holt, "Alternative Futures for the Development of Library Science Education: A View From Inside the Library,” in Education for the Library/Information Profession: Strategies for the Mid-1990s, ed. Patricia G. Reeling (Jefferson, NC: McFarland, 1993).

54. Beverly P. Lynch, "The Development of the Academic Library in American Higher Education and the Role of the Academic Librarian," in Leadership and Academic 
Librarians, ed. Terrence F. Mech and Gerard B. McCabe, Westport, CT: Greenwood Press, 1998, 19.

55. Michael F. Winter, The Professionalization of Librarianship, Champaign, IL: University of Illinois, Graduate School of Library and Information Science, 1983; Rice-Lively and Racine, “The Role of Academic Librarians in the Era of Information Technology.”

56. Richardson, Knowledge-Based Systems for General Reference Work: Applications, Problems, and Progress, 51.

57. Jesse Hauk Shera, Introduction to Library Science: Basic Elements of Library Service, Littleton, CO: Libraries Unlimited, 1976; F. W. Lancaster, "Future Librarianship: Preparing for an Unconventional Career,” Wilson Library Bulletin 57 (May 1983): 747-53.

58. Diana M. Thomas, Ann T. Hinckley, and Elizabeth R. Eisenbach, The Effective Reference Librarian, Orlando, FL: Academic Press, 1981; Patrick Wilson, Public Knowledge, Private Ignorance: Toward a Library and Information Policy, Westport, CT: Greenwood Press, 1977.

59. Wilson, Public Knowledge, Private Ignorance: Toward a Library and Information Policy.

60. Thomas Childers, “The Test of Reference,” Library Journal 105 (1980): 924-28; Peter Hernon and Charles R. McClure, "Unobtrusive Testing: The 55 Percent Rule,” Library Journal 111 (April 15, 1986): 37-41.

61. Joan C. Durrance, "Reference Success: Does the 55 Percent Rule Tell the Whole Story?” Library Journal 114 (April 15, 1989): 31-36; Jo Bell Whitlatch, 
“Unobtrusive Studies and the Quality of Academic Reference Services,” College \& Research Libraries 50 (March 1989): 181-94; Carolyn W Jardine, “Maybe the 55 Percent Rule Doesn’t Tell the Whole Story: A User-Satisfaction Survey,” College \& Research Libraries 56 (November 1995): 477-85; Loriene Roy, “Reference Accuracy,” Reference Librarian 49-50 (1995): 217-27; John V. Richardson, Jr., “Reference Is Better Than We Thought,” Library Journal 127 (April 15, 2002): 41-42.

62. Wilson, Public Knowledge, Private Ignorance: Toward a Library and Information Policy, 102-103.

63. Jo Bell Whitlatch, "Reference Service Effectiveness,” RQ 30 (Winter 1990): 205-20.

64. Richardson, Knowledge-Based Systems for General Reference Work: Applications, Problems, and Progress, 51.

65. Thomas, Hinckley, and Eisenbach., The Effective Reference Librarian, 5.

66. Jo Bell Whitlatch, Evaluating Reference Services: A Practical Guide, Chicago: American Library Association, 2000.

67. Roma M. Harris and Gillian B. Michell, "The Social Context of Reference Work: Assessing the Effects of Gender and Communication Skill on Observers' Judgments of Competence,” Library and Information Science Research 8 (January 1986): 85-101.

68. Brian Quinn, "Beyond Efficacy: The Exemplar Librarian As a New Approach to Reference Evaluation,” Illinois Libraries 76 (Summer 1994): 163-73.

69. Michael F. Winter, The Culture and Control of Expertise: Toward a Sociological Understanding of Librarianship, Westport, CT: Greenwood Press, 1988, 4. 
70. Ibid., 25.

71. Ibid., 24.

72. Ibid., 27.

73. Shera, Introduction to Library Science: Basic Elements of Library Service.

74. Asheim, “Librarians As Professionals,” 249.

75. William J. Goode, “The Librarian: From Occupation to Profession,” Library Quarterly 31 (October 1961): 306-20; William Joseph Reeves, Librarians As Professionals: The Occupation's Impact on Library Work Arrangements, Lexington, MA: Lexington Books, 1980.

76. Thomas Gwinup, “The Failure of Librarians to Attain Profession: The Causes, the Consequences, and the Prospect,” Wilson Library Bulletin 48 (February 1974): 482.

77. Asheim, “Librarians As Professionals,” 230.

78. Winter, The Culture and Control of Expertise: Toward a Sociological Understanding of Librarianship, 26.

79. Winter, The Professionalization of Librarianship, 25.

80. Richardson, Knowledge-Based Systems for General Reference Work: Applications, Problems, and Progress, 41-42.

81. Gary Marchionini, Information Seeking in Electronic Environments, New York: Cambridge University Press, 1995.

82. Patrick V. Drotos, “Changing With the Times,” Online 18 (January 1994): 54-58. 83. Shera, The Foundations of Education for Librarianship, 203-204. 
84. California Library Association, “The Future of Librarianship,” Web page, 1996 [accessed 2 June 2002], Available at http://www.cla-net.org/pubs/future.html.

85. Shera, The Foundations of Education for Librarianship, 199.

86. Ibid., 202.

87. Ibid., 202-203.

88. John M. Budd, Knowledge and Knowing in Library and Information Science: A Philosophical Framework, Lanham, MD: Scarecrow Press, 2001, 186-201.

89. Kimmo Tuominen, "User-Centered Discourse: An Analysis of the Subject Positions of the User and the Librarian,” Library Quarterly 67 (October 1997): 352.

90. Ibid.

91. Gerhard Van der Linde, "Knowledge, Power and the Academic Library in Postmodern Society,” South African Journal of Library and Information Science 58 (September 1990): 249-54.

92. Gary P. Radford, "Flaubert, Foucault, and the Biblotheque Fantastique: Toward a Postmodern Epistemology for Library Science," Library Trends 46:4 (1998), 621.

93. Anne Marie Candido, "Fabricating and Prefabricating Language: Troubling Trends in Libraries,” Journal of Academic Librarianship 25 (November 1999): 433.

94. Suzanne M. Shultz, “Medical Jargon: Ethnography of Language in a Hospital Library,” Medical Reference Services Quarterly 15 (Fall 1996): 41-47; Rachael Naismith and Joan Stein, “Library Jargon: Student Comprehension of Technical Language Used by Librarians,” College and Research Libraries 50 (September 1989): 543-552. 
95. Naismith and Stein, “Library Jargon: Student Comprehension of Technical Language Used by Librarians.”

96. Ibid., 543.

97. Candido, “Fabricating and Prefabricating Language: Troubling Trends in Libraries,” 433.

98. Budd, Knowledge and Knowing in Library and Information Science: A Philosophical Framework, 327.

99. Winter, The Culture and Control of Expertise: Toward a Sociological Understanding of Librarianship, 27-29 and 84-87.

100. Crowley, “Tacit Knowledge and Quality Assurance: Bridging the Theory-Practice Divide."

101. Rice-Lively and Racine, "The Role of Academic Librarians in the Era of Information Technology,” 33.

102. Shera, The Foundations of Education for Librarianship. Drotos, “Changing With the Times;” Beverly P. Lynch and Kimberley Robles Smith, “The Changing Nature of Work in Academic Libraries,” College \& Research Libraries 62 (September 2001): 407-20; Catherine Sheldrick Ross and Patricia Dewdney, "Best Practices: An Analysis of the Best (and Worst) in Fifty-Two Public Library Reference Transactions,” Public Libraries 33 (September/October 1994): 261-66.

103. Patrick Wilson, Two Kinds of Power: An Essay on Bibliographical Control, Berkeley: University of California Press, 1968, 116.

104. Ibid., 115. 
105. Rice-Lively and Racine, "The Role of Academic Librarians in the Era of Information Technology,” 35.

106. Winter, The Culture and Control of Expertise: Toward a Sociological Understanding of Librarianship., 65-66.

107. Richardson, Knowledge-Based Systems for General Reference Work: Applications, Problems, and Progress, 24-26.

108. Marshall Eidson, "Using Emotional Intelligence in the Reference Interview,” Colorado Libraries 26 (Summer 2000): 8-10.

109. Brian Quinn, "How Psychotherapists Handle Difficult Clients: Lessons for Librarians,” The Reference Librarian 75/76 (2002): 181-196.

110. Julie J. McGowan and Elizabeth H. Dow, "Faculty Status and Academic Librarianship: Transformation to a Clinical Model,” Journal of Academic Librarianship 21 (September 1995): 345-350.

111. Anderson, “A Reflection on Client-Professional Collaboration,” 195.

112. Ibid.

113. Bonnie A. Nardi and Vicki O’Day, Information Ecologies: Using Technology With Heart, Cambridge, MA: MIT Press, 1999, 85.

114. Michele G. Hanson, “Joining the Conversation: Collaborative Learning and Bibliographic Instruction,” Reference Librarian 51/52 (1995): 147-59.

115. Nardi and O’Day, Information Ecologies: Using Technology With Heart, 86-87.

116. Ibid., 89-90.

117. Ibid., 91. 
118. Ibid., 92. Also see Michael Gorman, "Values for Human-to-Human Reference,” Library Trends 50 (Fall 2001): 168-182.

119. Budd, Knowledge and Knowing in Library and Information Science: A Philosophical Framework, 318-319.

120. Michael Gorman, Our Enduring Values: Librarianship in the $21^{\text {st }}$ Century, Chicago: American Library Association, 2000, 81

121. Welker, “Expertise and the Teacher As Expert: Rethinking a Questionable Metaphor,” 34-35.

122. Jean Sheridan, “The Reflective Librarian: Some Observations on Bibliographic Instruction in the Academic Library,” Journal of Academic Librarianship 16 (March 1990): 22-26.

123. Charles A. Bunge, “Beliefs, Attitudes and Values of the Reference Librarian,” Reference Librarian 66 (1999): 19-20.

124. Danuta A. Nitecki, “Changing the Concept and Measure of Service Quality in Academic Libraries,” Journal of Academic Librarianship 22 (May 1996): 181190.

125. Jardine, “Maybe the 55 Percent Rule Doesn’t Tell the Whole Story: A UserSatisfaction Survey,” 478.

126. Syed Saad Andaleeb and Patience L. Simmonds, "Explaining User Satisfaction with Academic Libraries: Strategic Implications,” College \& Research Libraries 59 (March 1998): 156-167; Elaina Norlin, “Reference Evaluation: A Three-Step Approach--Surveys, Unobtrusive Observations, and Focus Groups at the 
University of Arizona,” College \& Research Libraries 61 (November 2000): 546553.

127. Darlene E. Weingand, Customer Service Excellence: A Concise Guide for Librarians, Chicago: American Librarian Association, 1997.

128. Carole A. Larson and Laura K. Dickson, “Developing Behavioral Reference Desk Performance Standards,” RQ 33 (1994): 349-357; Marie L. Radford, “Approach or Avoidance? The Role of Nonverbal Communication in the Academic Library User’s Decision to Initiate a Reference Encounter,” Library Trends 46 (Spring 1998): 699-718.

129. Joan Durrance, “Factors that Influence Reference Success: What Makes Questioners Willing to Return?” Reference Librarian 49/50 (1995): 243-265.

130. Umberto Eco, The Name of the Rose (San Diego: Harcourt Brace Jovanovich, 1983).

131. Fleck, "Expertise, Knowledge, Power and Tradeability,” 147.

132. Shera, The Foundations of Education for Librarianship, 203-204.

133. Eidson, “Using Emotional Intelligence in the Reference Interview,” 8.

134. Daniel Coffey and Karen Lawson, "Managing Meaning: Language and Technology in Academic Libraries,” College \& Research Libraries 63 (March 2002): 151162.

135. David A. Tyckoson, “Wrong Questions, Wrong Answers: Behavioral vs. Factual Evaluation of Reference Service,” Reference Librarian 38 (1992): 151-173; Jardine, “Maybe the 55 Percent Rule Doesn’t Tell the Whole Story: A UserSatisfaction Survey,” 477. 
136. Tobeylynn Birch and Jan Wilson, “Information-Seeking Behavior of Professional Psychologists,” presented October 2, 1998, in Santa Monica, CA, at the Annual Meeting of the Association of Mental Health Librarians.

137. Gorman, "Values for Human-to-Human Reference;” Gorman, Our Enduring Values: Librarianship in the $21^{\text {st }}$ Century.

138. Hanson, “Joining the Conversation: Collaborative Learning and Bibliographic Instruction,”147.

139. Tyckoson, “Wrong Questions, Wrong Answers: Behavioral vs. Factual Evaluation of Reference Service,”153.

140. Richard E. Bopp and Linda C. Smith, Reference and Information Services: An Introduction, Englewood, CO: Libraries Unlimited, 1995, 42-43.

141. Ibid., 264-265.

142. Bunge, "Beliefs, Attitudes and Values of the Reference Librarian,” 19-20.

143. Schon, The Reflective Practitioner: How Professionals Think in Action.

144. Ibid., 296-297.

145. Gorman, Our Enduring Values: Librarianship in the $21^{\text {st }}$ Century, 78; Andaleeb and Simmonds, 159.

146. McGowan and Dow, "Faculty Status and Academic Librarianship: Transformation to a Clinical Model,” 348.

147. Anderson, Conversation, Language, and Possibilities: A Postmodern Approach to Therapy.

148. Anderson, “A Reflection on Client-Professional Collaboration,” 199. 
149. Naismith and Stein, “Library Jargon: Student Comprehension of Technical Language Used by Librarians,” 543.

150. Coffey and Lawson, "Managing Meaning: Language and Technology in Academic Libraries,” 161.

151. Gorman, “Values for Human-to-Human Reference,” 171. 